\title{
THE ORIGIN OF MAMMALS: CHRONOLOGY AND PALEOBIOGEOGRAPHY
}

LUCAS*, Spencer G. and HUNT, Adrian P., New Mexico Museum of Natural History, 1801 Mountain Road N. W., Albuquerque, NM 87104 U.S.A.

A comprehensive review of the stratigraphic and geographic distribution of the advanced, non-mammalian cynodonts (traversodontids, tritylodontids and tritheledontids) and the Late Triassic-Early Jurassic mammals indicates that: (1) traversodontids were a wholly Triassic group that disappeared during the Rhaetian; during the late Carnian-early Norian they were rare but widespread components of Pangaean land-vertebrate faunas; (2) tritylodontids first appeared in Europe during the Rhaetian, were a cosmopolitan group by the Sinemurian/Pliensbachian and disappeared during the Bathonian; (3) tritheledontids ranged in age from late Carnian to Sinemurian/Pliensbachian and were mostly a New World group; and (4) the oldest mammal is of late Carnian age from West Texas, but there is at least a 10-million-year gap between it and the next oldest mammals from the late Norian of Europe.

Advanced cynodont and mammalian distributions of the Late Triassic-Early Jurassic do not suggest Late Triassic paleoprovinciality, but they do support the notion of a cosmopolitan vertebrate fuuna during the Sinemurian/Pliensbachian. Proponents of a tritylocuntid ancestry of mammals must explain away a 15-million-year-long absence of tritylodontids from the Late Triassic fossil record. In contrast, proponents of a tritheledontid ancestry of mammals need offer no such explanation since tritheledontids and mammals appeared simultaneously during the late Carnian. 